Beata Bilicka*

Toruń

\title{
Wkład ks. W. Gadowskiego i ks. Z. Bielawskiego w przezwyciężenie modelu katechizmu deharbowskiego w Polsce na początku XX wieku
}

Początek XX wieku to okres nowego spojrzenia na problemy katechetyczne i czas dyskusji nad zagadnieniem treści nauczania. W Polsce głównymi przedstawicielami pionierskiego spojrzenia na ujęcie treści nauczania w katechezie byli dwaj najwybitniejsi katechetycy tego okresu: ks. W. Gadowski - zwolennik włączenia do katechizmu historii biblijnej, liturgiki, tekstów Ojców Kościoła i hagiografii, oraz ks. Z. Bielawski - propagator ograniczenia treści katechizmu do minimum i przydzielenia mu miejsca na końcu katechezy jako streszczenia całej lekcji. Wyrazem tych odmiennych poglądów były katechizmy i podręczniki, które opublikowali niemal w tym samym czasie ${ }^{1}$, dzisiaj znane zapewne już tylko starszym katechetom, ale zasługujące jednak w pełni na przypomnienie. Obaj katechetycy wnieśli również twórczy wkład w propagowanie tzw. metody monachijskiej i wypracowanie zmodyfikowanego modelu katechezy opartej na teorii stopni formalnych ${ }^{2}$. Niniejszy artykuł ma na celu ukazać - w pewnym zarysie - wkład ks. W. Gadowskiego i ks. Z. Bielawskiego w przezwyciężenie modelu katechizmu deharbowskiego obecnego w nauczaniu prawd wiary od połowy XIX wieku.

* Beata Bilicka - dr teologii, adiunkt w Zakładzie Katechetyki i Pedagogiki Religii na Wydziale Teologicznym UMK w Toruniu, ekspert MEN do spraw awansu zawodowego nauczycieli.

${ }^{1}$ Por. M. Rusiecki, Katechizm, w: Encyklopedia katolicka, t. VIII, Lublin 2000, kol. 1046.

${ }^{2}$ Por. J. Szpet, Ważniejsze akcenty w polskiej katechezie XX wieku, Katecheta 44/2000, nr 2, s. 7. 


\section{Katechizmy ks. Walentego Gadowskiego}

Trudno w ramach niniejszego artykułu opisać wszystkie zasługi ks. Walentego Gadowskiego (1861-1956) dla polskiej katechezy okresu międzywojennego. Zasłynął on przede wszystkim jako inicjator poszukiwania nowych metod w katechetyce i pedagogice polskiej. W czasie, kiedy na Zachodzie używano jeszcze katechizmu Józefa Deharbe, napisał katechizmy, które propagowały nowy sposób przekazu prawd wiary ${ }^{4}$, ,ukazywały znamiona przemian i charakter awangardowy”. Przeniósł do polskiej katechezy i ulepszył metodę monachijska, nazwaną na kongresie katechetycznym w Monachium w 1913 roku Gadowskische methode. Przejął od profesora Uniwersytetu w Dilingen Antona Webera pięciostopniowy układ treści lekcji, ale nadał mu nieco inny charakter - przeniósł wykład ze stopnia drugiego na trzeci w miejsce wyjaśnienia, a w czwartym stopniu jednostki metodycznej zaproponował pogłębienie zamiast skupienia. Przeciwstawił się zbyt skomplikowanemu dochodzeniu do pojęć przy zastosowaniu tylko jednego poglądu; postulował potrzebę stosowania kilku uzmysłowień, poglądów, zwłaszcza wówczas, gdy prawda katechizmowa zawiera kilka odrębnych części ${ }^{6}$. W ten sposób udało się przezwyciężyć metodę dedukcyjną (tzw. egzegetyczną, objaśniająca) stosowaną w nauczaniu w XIX wieku. Odtąd coraz większą popularnością zaczęła cieszyć się nowa metoda - indukcyjna, zwana również naprowadzająca. Stopnie jednostki lekcyjnej według „starej” i „nowej” metody przedstawia poniższa tabela.

\begin{tabular}{|c|c|c|}
\hline \multicolumn{3}{|c|}{ Stopnie jednostki lekcyjnej (katechetycznej) } \\
\hline $\begin{array}{c}\text { Wg metody } \\
\text { dedukcyjno-egzegetycznej }\end{array}$ & $\begin{array}{c}\text { Wg A. Webera } \\
\text { (metoda monachijska) }\end{array}$ & $\begin{array}{c}\text { Wg ks. W. Gadowskiego } \\
\text { (metoda Gadowskiego) }\end{array}$ \\
\hline 1. Czytanie (lectio) & $\begin{array}{c}\text { 1. Zapowiedź treści, } \\
\text { przygotowanie }\end{array}$ & $\begin{array}{c}\text { 1. Przygotowanie } \\
\text { (praeparatio) }\end{array}$ \\
\hline 2. Wyjaśnienie (explicatio) & 2. Wykład & 2. Pogląd (perceptio) \\
\hline 3. Zastosowanie (applicatio) & 3. Wyjaśnienie & 3. Wykład (propositio) \\
\hline & 4. Skupienie & 4. Pogłębienie (explicatio) \\
\hline & 5. Zastosowanie & 5. Zastosowanie (applicatio) \\
\hline
\end{tabular}

${ }^{3}$ Zob. M. Banduła, Gadowski Walenty, w: Stownik katechetyków polskich XX wieku, red. R. Czekalski, Warszawa 2003, s. 63-65; P. Poręba, Gadowski Walenty, w: Encyklopedia katolicka, t. V, Lublin 1989, kol. 800-801; tenże, Gadowski Walenty, w: Stownik polskich teologów katolickich 1918-1981, red. L. Grzebień, t. V, Warszawa 1983, s. 417-419.

${ }^{4}$ Por. J. Stala, Skuteczność wychowawczych oddziatywań rodziców wedtug ks. Walentego Gadowskiego, w: W. Gadowski, Wspomnienia katechety, Bochnia ok. 1950, s. 271.

${ }^{5}$ P. Poręba, Dzieje katechetyki, w: Dzieje teologii katolickiej w Polsce, t. 3, cz. 2, red. M. Rechowicz, Lublin 1977, s. 137.

${ }^{6}$ Por. J. Dajczak, Ks. Gadowski Walenty jako pedagog, Homo Dei 20/1951, nr 5-6, s. 618-619.

${ }^{7}$ Por. W. Kubik, Ksiadz Walenty Gadowski (1861-1956), Ksiadz Zygmunt Bielawski (1877-1939), 
Zgodnie z założeniami metody naprowadzającej ks. Gadowski był „Zwolennikiem katechizmu indukcyjnego, poglądowego i elementarnego, przy zachowaniu w treści nauczania tradycji Kościoła i jego ducha" elementarny, tj. postępuje od rzeczy znanych do nieznanych, od łatwych do trudniejszych. [...] jest dostosowany do racjonalnych wymogów szkoły twórczej i wiąże stale religię z życiem. Cytaty z Ewangelii i z soborów czynią nauczanie źródłowym. Przez omawianie obrzędów, w Polsce używanych, ma charakter swojski. Przy każdej lekcji podaje zwrotkę odpowiedniej pieśni religijnej. Wprowadza osobno lekcje repetycyj$n e$, by wskazać minimum ćwiczenia potrzebnego".

Ks. Walenty Gadowski jest autorem licznych podręczników do nauki religii, które można podzielić na trzy kategorie: dzieje biblijne; katechizmy; podręczniki do nauki historii Kościoła - dla szkół średnich napisał Zarys historii Kościoła, a dla szkół powszechnych Krótka historię Kościoła w formie życiorysów i konkretnych obrazów dziejowych ${ }^{10}$. Opracował także modlitewnik dla dzieci Dobry Pasterz, którego pierwsze wydanie ukazało się w 1912 roku; dla katechetów wydał Nauki katechizmowe, Przygotowanie do pierwszej Komunii św. (Kraków 1919) oraz Biblijne katechezy elementarne dla dziatwy I i II roku nauki w szkołach wiejskich (Tarnów 1912); uzupełnił również, za zgodą autora, Ilustrowany krótki katechizm rzymsko-katolicki ks. Edwarda Likowskiego (Tarnów 1906), ułożony według Deharbe, próbując dostosować go do nowych wymagań metodycznych. Tego typu przeróbka nie przyniosła jednak oczekiwanych efektów, dlatego ks. Gadowski, wykorzystując tradycyjny schemat: Skład Apostolski, Dekalog, sakramenty św., napisał nowy katechizm, którego struktura nawiązywała do katechizmów św. Piotra Kanizjusza (wiara - Skład Apostolski; nadzieja - modlitwa; miłość - przykazania; a na końcu sakramenty i sprawiedliwość chrześcijańska), a odeszła od układu Józefa Deharbe (Skład Apostolski, przykazania, sakramenty i modlitwa). Do katechizmu wprowadził Gadowski wyjaśnienia liturgiczne, przykłady z życia świętych, pieśni kościelne, modlitwy, a także ilustracje, dotychczas nieobecne $\mathrm{w}$ katechizmach ${ }^{11}$. Zastosowanie ilustracji wzbudziło ostrą krytykę, dlatego że nikt dotąd nie ilustrował teologii czy filozofii, na którą autor odpowiadal, że ,katechizm szkolny nie powinien ani być teologią, ani filozofią, lecz powinien zniżać się do pojętności dzieci” ${ }^{12}$. Zdaniem J. Dajczaka, katechizmy te za-

w: red. R. Czekalski, Sto lat polskiej katechezy, Wkład wybitnych polskich katechetyków w odnowe i rozwój polskiej katechezy, Kraków 2001, s. 14-18.

${ }^{8}$ Tamże, s. 17.

${ }^{9}$ W. Gadowski, W sprawie reformy katechizmu dla dzieci, Przegląd Katechetyczny 31/1948, nr 6-7, s. 193, 195.

${ }^{10}$ Tenże, Zarys historji Kościoła katolickiego dla szkół średnich i seminariów nauczycielskich, Kraków 1904; tenże, Zarys historji Kościoła katolickiego dla szkót średnich i seminariów nauczycielskich, cz. II, wyd. VI, Lwów-Warszawa 1927; tenże, Krótka historja Kościoła katolickiego dla siódmej klasy powszechnej, wyd. II powiększone, Tarnów 1927.

${ }^{11}$ Por. H. Weryński, Zastużonemu nestorowi katechetyki w hołdzie, Miesięcznik Katechetyczny i Wychowawczy 23/1934, z. 8, s. 327-328.

${ }^{12}$ W. Gadowski, Wspomnienia katechety, s. 138. 
wierały już ilustracje, które weszły w powszechne zastosowanie dopiero około 1935 $\mathrm{roku}^{13}$.

Ks. Gadowski napisał książki dostosowane do wieku odbiorcy; były to katechizmy dla dzieci, młodzieży, dorosłych. Jako pierwszy wyszedł Ilustrowany katechizm średni dla katolików (Kraków 1906), a następnie Katechizm religii rzymsko-katolickiej dla dzieci (Tarnów 1912). Ten ostatni wydano w jednym woluminie z Dziejami biblijnymi w skróceniu dla dzieci katolickich ${ }^{14}$. Katechizm dla dzieci składał się z trzech zasadniczych części:

1. Modlitwy najpotrzebniejsze.

2. Katechizm szczegółowy.

3. Dodatek zawierający: Katechizm ogólny, Przygotowanie do spowiedzi, Ministranturę.

Zasadnicza treść podręcznika zawarta została w tzw. Katechizmie szczegółowym, który dzieli się na pięć części: O wierze katolickiej (28 jednostek), O modlitwie i nadziei chrześcijańskiej ( 7 jednostek), O przykazaniach i obowiązkach (18 jednostek), O sakramentach św. i sakramentaliach (15 jednostek), O Mszy świętej (5 jednostek). Każda z pięciu części dzieli się na mniejsze jednostki, które zamyka jednostka powtórkowa zwana lekcja repetycyjnq. Autor odszedł od tradycyjnego deharbowskiego podziału katechizmu na pytania i odpowiedzi, a zastosował nową strukturę jednostki tematycznej: czytanka osnuta na tle Pisma Świętego, a po niej pytania i odpowiedzi. O takiej budowie katechizmu Gadowski twierdził:

Apelujemy zatem na wstępie do religijnych przeżyć dziecka, a nie do jego rozumu, który jeszcze za mało jest rozwinięty, zatem trzymajmy się układu Kanizjusza, a nie Deharbea. [...] U Deharbea modlitwa zepchnięta jest na koniec katechizmu, a przecież w życiu religijnym dziecka wysuwa się ono [sic! - ona] na plan pierwszy. O nadziei uczy tylko przy pierwszym przykazaniu dekalogu, a tymczasem cnota nadziei jest nader ważną dźwignią w życiu chrześcijańskim. Naukę o grzechach i cnotach odrywa od nauki o przykazaniach Boskich, czyli pozbawia ją tła naturalnego i czyni ją czymś sztucznym. Tak samo naukę o łasce Bożej odrywa od nauki o Duchu Świętym ${ }^{15}$.

Ks. W. Gadowski starał się opracować katechizm elementarny, który zawierałby bogatą treść powiązaną z życiem, opartą na zasadach elementarności i poglądowości ${ }^{16}$. Wprowadził do katechizmu stronę liturgiczną obrzędów katolickich, teksty pieśni religijnych (w Katechizmie dla dzieci umieścił 20 fragmentów różnych pieśni) i modlitw, żywoty świętych, a więc to co stanowi przejawy życia chrześcijańskiego

\footnotetext{
${ }^{13}$ Por. J. Dajczak, Ruch katechetyczny w bieżacym stuleciu, Katecheta 2/1958, nr 1, s. 21.

${ }^{14}$ W. Gadowski, Katechizm katolicki dla dzieci i dzieje biblijne, Tarnów 1912.

${ }^{15}$ Tenże, Wspomnienia katechety, s. 140-141.

${ }^{16}$ Tamże, s. 141.
} 
w codziennym życiu. Nowością jest także oddzielny dział o Mszy św. ${ }^{17}$ umieszczony na końcu katechizmu, ponieważ jak podkreślał sam autor:

Na końcu katechizmu można o Mszy św. uczyć dokładnie, zużytkowując dekalog i naukę o Najświętszym Sakramencie, a pogłębiając ideę ofiary najdoskonalszej, jako nieustannego objawu miłości, mądrości, wszechmocy Bożej. Msza św. nadaje się wybornie do powtórzenia całego katechizmu. Ufam, że przez taki układ katechizm nie stracił, owszem zyskał na wartości praktycznej, bo stał się chrystologiczny ${ }^{18}$.

Katechizm religii rzymsko-katolickiej dla dzieci wydany został także w przekładzie niemieckim, książka pt. Katholischer katechismus für Kinder, Entwurf für Religionslerhrer, als Manuskript gedruck ukazała się we Wiedniu w 1913 roku, autor opublikował ją pod pseudonimem „Simplex”19. W Polsce katechizm doczekał się kilkunastu różnych edycji - późniejsze dzieliły treść na dwa katechizmy ${ }^{20}$ : jeden - tzw. mały (230 stron $)^{21}$ - dla czteroklasowych szkół powszechnych, a więc na stopień niższy (I i II rok nauki w szkole powszechnej) oraz średni (klasy III i IV); drugi - tzw. większy (336 stron $)^{22}$ - dla siedmioklasowych szkół powszechnych, a więc na stopień niższy, średni i wyższy (klasy V, VI, VII). Publikowano także skróty i wyciagi z katechizmu ${ }^{23}$. W 939 roku wyszedł obszerny, liczący ponad 480 stron $^{24}$. Apologetyczny katechizm dla dorostych ${ }^{25}$ składający się z trzech części: części dogmatycznej pt. Nauka wiary (61 jednostek, a w nich łącznie 168 pytań i odpowiedzi); części etycznej pt. Nauka moralności chrześcijańskiej (56 jednostek, 129 pytań); części liturgicznej pt. Część liturgiczna (33 jednostki, 103 pytania). Struktura jednostki tematycznej dla dorosłych przypomina jednostkę katechizmu dla dzieci - najpierw tekst narracyjny - pogadanka, a po nim pytania i odpowiedzi; różni się jednak brakiem ilustracji.

${ }^{17}$ W. Gadowski, Katechizm religii rzymsko-katolickiej dla dzieci, w: tenże, Katechizm katolicki..., s. 433-444.

18 Tenże, Wspomnienia katechety, s. 143.

${ }^{19}$ Por. tamże.

${ }^{20}$ Recenzent katechizmu ks. Z. Bielawski postulował jeszcze inny podział treści, a mianowicie oddzielenie stopnia średniego od stopnia wyższego; por. Z. Bielawski, Nowy katechizm, Miesięcznik Katechetyczny i Wychowawczy 6/1917, z. 1, s. 49.

${ }^{21} \mathrm{~W}$. Gadowski, Ilustrowany maty elementarny katechizm katolicki dla 4-klasowych szkót powszechnych, wyd. IV, Lwów-Warszawa 1922.

${ }^{22}$ Tenże, Ilustrowany większy elementarny katechizm katolicki dla 7-klasowych szkót powszechnych, wyd. IV, Lwów-Warszawa 1922.

${ }^{23}$ Tenże, Dodatek katechizmowy do większego katechizmu elementarnego dla dorostych i młodzieży, wyd. I, Tarnów 1918; Katechizm krótki, wyciag z elementarnego katechizmu katolickiego x. W. Gadowskiego, wyd. VIII, Bochnia 1938.

${ }^{24}$ Tenże, Apologetyczny katechizm katolicki, Miejsce Piastowe 1939.

${ }^{25}$ Ks. Gadowski twierdził, że 400 pytań i odpowiedzi zawartych w Apologetycznym katechizmie dla dorostych w połączeniu z Katechizmem elementarnym nadawałoby się jako podręcznik dla liceów; por. W. Gadowski, W sprawie reformy..., s. 195. 
Zgodnie z tezą dydaktyczną: ,nauczanie katechizmu musi opierać się na Biblii”"26, Gadowski opracował nowy typ biblijki - elementarnej, dostosowanej do możliwości poznawczych uczniów, w której zredukował materiał ze Starego Testamentu, niezrozumiały często dla młodszych dzieci. Jemu zawdzięczamy także ,propagandę umiaru w pogodzeniu Bibliji z Katechizmem"27. W 1907 roku w Tarnowie wyszły po raz pierwszy Dzieje biblijne w skróceniu dla dzieci katolickich, a dziesięć lat później Mała biblijka zawierajaca cała naukę religii dla dzieci pierwszej i drugiej klasy ludowej (Tarnów 1917). Dzieje biblijne podzielone zostały na cztery części:

1. Dzieje objawienia pierwotnego - od stworzenia świata i upadku Aniołów do synów Noego (10 jednostek).

2. Dzieje Starego Przymierza - od powołania Abrahama do króla Heroda Okrutnego (41 jednostek).

3. Dzieje Nowego Przymierza - od zwiastowania narodzin Jana Chrzciciela do wniebowstapienia Pana Jezusa (70 jednostek).

4. Dzieje Apostolskie - od zesłania Ducha Świętego do podróży apostolskich św. Pawła Apostoła (10 jednostek).

Całość składa się z 131 jednostek tematycznych, w których autor wydzielił poprzez oznaczenia krzyżykiem, gwiazdką lub brak oznaczeń - partie materiału dla klas I i II, klas III i IV, klas V i VI ${ }^{28}$. Jednostki napisane zostały w formie narracyjnej, bez pytań i odpowiedzi. Książkę ubogacają liczne czarno-białe obrazki ilustrujące wydarzenia biblijne, jest ich 110 oraz jedna mała mapka Palestyny. W późniejszych wydaniach zmieniono oraz zmniejszono liczbę ilustracji, a dodano dwie mapki ${ }^{29}$.

Ksiądz Walenty Gadowski otworzył nowy etap w rozwoju katechizmu w Polsce ${ }^{30}$. Ubogacił go metodycznie (pogadanka, a po niej dopiero pytania i odpowiedzi), wprowadził ilustracje, pogłębił teologicznie w duchu chrystocentryzu (wprowadził teksty biblijne, patrystyczne, obrzędy liturgiczne, przykłady z życia świętych, pieśni religijne). Jest autorem nowego typu biblijki, „zapoczątkował on rozwój katechezy biblijnej we właściwym kierunku. Jego prace stanowią ważny etap w rozwoju polskiej myśli katechezy biblijnej”31.

${ }^{26}$ A. Solak, Wychowawcze aspekty działalności ks. Walentego Gadowskiego, w: W. Gadowski, Wspomnienia katechety, s. 284.

${ }^{27}$ H. Weryński, Zastużonemu nestorowi..., s. 328.

${ }^{28}$ Por. W. Gadowski, Dzieje biblijne w skróceniu dla dzieci katolickich, Tarnów [nie wcześniej niż 1906] w: tenże, Katechizm katolicki..., s. 4.

${ }^{29}$ Zob. tenże, Dzieje biblijne w skróceniu dla gimnazjum niższego i szkót powszechnych z 44 ilustracjami i 3 mapkami, wyd. VIII powiększone, Lwów-Warszawa 1930.

${ }^{30}$ Ks. Gadowski tak oceniał swój wkład w rozwój polskiego katechizmu: „Ufam, że idea specjalnego katechizmu dla dzieci wcześniej czy później zwycięży, bo pragnienie przychylenia nieba duszom dziecięcym weźmie górę nad niefortunnym przyzwyczajeniem. Może być, że ów katechizm przyszłości będzie odmienny od mojego, ale pocieszam się przeświadczeniem, że swoją próbą utorowałem mu drogę. In magnis et voluisse satis est"; W. Gadowski, Wspomnienia katechety, s. 145.

${ }^{31}$ A. Solak, Wychowawcze aspekty..., s. 286. 


\section{Podręczniki ks. Zygmunta Bielawskiego}

Duży wkład w propagowanie w Polsce wspomnianej już metody monachijskiej i stosowanie jej w opracowanych przez siebie materiałach katechetycznych wniósł ks. Zygmunt Bielawski (1877-1939) ${ }^{32}$. Podobnie jak ks. W. Gadowski uznawał dwie metody - dedukcyjną (objaśniająca) i indukcyjną (naprowadzająca), ale w przeciwieństwie do Gadowskiego, który mówił o podwójnym toku nauczania, ks. Bielawski używał określenia metoda. Metodę indukcyjną zalecał stosować w klasach młodszych w celu zapoznania uczniów z pojęciami religijno-moralnymi, w klasach starszych preferował metodę dedukcyjną. Wyróżniał trzy główne stopnie przyswajania pojęć przez uczniów: wykład, wyjaśnienie, zastosowanie, a także wypracował szereg stopni pośrednich. W stopniach głównych nie wyodrębnił poglądu, ponieważ wprowadzał go podczas wykładu ${ }^{33}$. Jego zasługą jest, że ,jako teoretyk podniósł katechetykę do rangi dyscypliny naukowej przez włączenie w nią pedagogiki i psychologii. Poszerzył zakres jej strony dydaktycznej. Scalił organicznie jej działy w jeden zwarty system. Katechetyka w jego ujęciu, jako pedagogika religijno-moralna, utrzymała w pełni swój wymiar dyscypliny teologicznej”34.

Ksiądz Z. Bielawski wniósł również twórczy wkład w poszukiwanie formy „,na wskroś nowoczesnego podręcznika zawierającego katechezy biblijno-liturgiczno-katechizmowe" 35 . Jest autorem kilku podręczników dla klas II-VI szkoły powszechnej ${ }^{36}$, które drukowano nawet w latach sześćdziesiątych $\mathrm{XX}$ wieku ${ }^{37}$. Opowiadał się za zredukowaniem do minimum treści katechizmu, starał się prawdy wiary przedstawić dzieciom $\mathrm{w}$ formie łatwych i przystępnych opowiadań z nielicznymi pytaniami i odpowiedziami; „dzięki temu katechizm zmienia ujęcie z przedmiotowego na zdecydowanie podmiotowe"38. Podręczniki, które wyszły spod jego pióra są „szczuplejsze” od katechizmów ks. Gadowskiego. Bielawski nie nazywa je katechizmami, lecz podręcznikami do nauki religii, chociaż zbudował je na podstawie tradycyjnego schematu katechizmowego obejmującego Skład Apostolski, modlitwę, przykazania, sakramen-

${ }^{32}$ Zob. M. Banduła, Bielawski Zygmunt, w: R. Czekalski, Stownik katechetyków..., s. 19-22; P. Poręba, Bielawski Zygmunt, w: Encyklopedia katolicka, t. II, Lublin 1985, kol. 532; L. Grzebień, Bielawski Zygmunt, w: red. L. Grzebień, Stownik polskich teologów..., s. 101-104.

${ }^{33}$ Por. W. Kubik, dz. cyt., s. 27-29.

${ }^{34}$ M. Rusiecki, Teoria katechezy w ujęciu ks. Zygmunta Bielawskiego (1877-1939), Nasza Przeszłość 32/1977, t. 48, s. 288.

${ }^{35}$ Tenże, Ksiqdz Zygmunt Bielawski wobec nurtów w katechezie polskiej (1910-1939), Roczniki Teologiczno-Kanoniczne 29/1977, t. 24, z. 6, s. 41.

${ }^{36}$ Udało mi się dotrzeć do dwóch podręczników: Stużba Boża oraz Dzieje biblijne Starego i Nowego Testamentu.

${ }^{37}$ Zob. B. a., Historia biblijna Starego i Nowego Testamentu, Opracowanie Diecezjalne Ślaska Opolskiego wedlug ks. dr Zygmunta Bielawskiego, Opole 1961. Jest to niezmieniona co do treści, ale z nowymi rycinami, kolejna edycja podręcznika Dzieje biblijne Starego i Nowego Testamentu ks. Z. Bielawskiego wydanego we Lwowie w 1936.

${ }^{38}$ M. Rusiecki, Katechizm, kol. 1046. 
ty. Przykładem takiego podręcznika jest Stużba Boża wydana w 1937 roku we Lwowie. W przedmowie autor wyjaśnia dzieciom, że całe nasze życie powinno być służbą Bożą, a to oznacza, że powinniśmy wierzyć w Pana Boga, pokładać w Nim nadzieję, kochać Go, zachowywać w duszy łaskę Bożą. Są to obowiązki dziecka katolickiego, o których dowie się uczeń w czasie lektury podręcznika. Dzięki służbie Bogu dziecko może być szczęśliwsze $\mathrm{w}$ życiu doczesnym i później $\mathrm{w}$ niebie ${ }^{39}$. Podręcznik składa się zatem z czterech zasadniczych części, które dzielą się na mniejsze jednostki tematyczne:

1. O wierze i Składzie Apostolskim (2 jednostki o wierze katolickiej i 27 jednostek na temat Składu Apostolskiego).

2. O nadziei i modlitwie (5 jednostek).

3. O miłości chrześcijańskiej i o przykazaniach (3 jednostki o miłości chrześcijańskiej, 5 jednostek o Dekalogu i przykazaniach kościelnych, 6 jednostek o sprawiedliwości chrześcijańskiej).

4. O łasce i świętych sakramentach (2 jednostki o łasce Bożej i 11 jednostek o sakramentach świętych).

Podstawowe prawdy wiary autor stara się przedstawić dzieciom w prosty i zrozumiały dla nich sposób, dlatego stosuje opowiadanie, a po nim pytania, nad którymi uczeń ma się zastanowić, są one posumowaniem całej jednostki. W niektórych miejscach zamieszcza teksty modlitw: akt wiary, modlitwę do Anioła Stróża, modlitwę do Jezusa Chrystusa wywyższonego, akt nadziei, Ojcze nasz, Pozdrowienie anielskie, modlitwe Anioł Pański, akt miłości ${ }^{40}$. Wykorzystuje także fragmenty trzech pieśni religijnych: Kto się w opieke, Spuśćcie nam na ziemskie niwy, Sekwencję do Ducha Świętego ${ }^{41}$. Książka zawiera ponadto 13 rycin ilustrujących wydarzenia biblijne oraz 8 czarno-białych zdjęć przedstawiających Piusa XI, Rzym, Jasną Górę, Lwów, Wilno oraz trzy obrazy maryjne ${ }^{42}$. W podręczniku widać troskę autora o prostotę języka, umiar w doborze treści i dostosowanie jej do możliwości percepcyjnych dziecka.

Innym podręcznikiem ks. Bielawskiego są Dzieje biblijne Starego i Nowego Testamentu wydane po raz pierwszy w 1928 roku, przeznaczone dla niższych klas szkół średnich i wyższych oddziałów szkół powszechnych. Książka podzielona została na dwie części: Stary Testament (37 jednostek) i Nowy Testament (83 jednostki), które kończą się każdorazowo podsumowaniem zwanym pogladem ${ }^{43}$. Całość poprzedza wstęp na temat Pisma Świętego, w którym autor zwraca się do czytelnika, aby szanował książkę i „,czytał ją z nabożeństwem”, ponieważ zawiera Słowo Boże ${ }^{44}$. Podręcz-

${ }^{39}$ Por. Z. Bielawski, Stużba Boża, Podręcznik do nauki religii rzymsko-katolickiej dla IV klasy szkót powszechnych, Podręcznik szkolny zatwierdzony rozp. MIN. W. R. i O. P. z dnia 19 czerwca 1937 nr II pr. 14864/17, Lwów 1937, s. 3.

${ }^{40}$ Tamże, s. 6, 24-25, 58, 84, 90, 92, 94, 96.

${ }^{41}$ Tamże, s. 16, 33, 64.

${ }^{42}$ Tamże, s. 70-71, 155-157.

${ }^{43}$ Por. Z. Bielawski, Dzieje biblijne Starego i Nowego Przymierza dla niższych klas szkót średnich i dla wyższych oddziałów szkót powszechnych, Podręcznik szkolny dozwolony rozp. Min. W. R. i O. P. z dnia 5 lutego 1932, nr 1 pr. 8015/31, wyd. III, Lwów 1936, s. 112-117, 292.

${ }^{44}$ Por. tamże, s. 7. 
nik zawiera zarys historii biblijnej, przy czym już samo zestawienie liczby jednostek wskazuje na znaczną redukcję materiału Starego Testamentu na korzyść Nowego. Taka redukcja, konieczna ze względu na potrzebę dostosowania treści materiału do możliwości uczniów, budziła jednak pewne uwagi ze strony ówczesnego recenzenta, który wskazywał na brak w podręczniku znanych i pięknych ustępów Starego Testamentu opisujących między innymi kobiety, takie jak: Rebeka, Estera, Sara, Rachel ${ }^{45}$. Dzieje biblijne to podręcznik, który łączy prawdy katechizmowe z treściami biblijnymi, co odzwierciedla struktura poszczególnych jednostek - składają się one z tekstów biblijnych oraz pytań i odpowiedzi zastosowanych w niektórych jednostkach, które autor uzgodnił z Większym katechizmem rzymsko-katolickim Archidiecezji Lwowskiej obrzadku łacińskiego ${ }^{46}$. Autor ,przekonany, iż słowo Boże zawsze prędzej trafi do duszy młodocianej, niż ludzkie, dla zasad dogmatycznych szuka dowodu nie tyle w logicznych, rozumowych rozważaniach, ile raczej w zwięzłych, a umiejętnie dobranych tekstach Pisma św." ${ }^{47}$ Testy biblijne zaczerpnięte z Pisma Świętego w przekładzie ks. Jakuba Wujka nie są dosłownymi cytatami; ks. Bielawski podzielił poszczególne perykopy na mniejsze części i zatytułował je (tytuły zaznaczono pogrubioną czcionką), dodał własne wyjaśnienia w formie przypisów i wyraźnie zaznaczył, z których ksiag i rozdziałów pochodzą przytaczane fragmenty. Całość wzbogacają liczne ryciny, które ilustrują i dodatkowo wyjaśniają tekst biblijny; na końcu podręcznika znajduje się mapa Palestyny.

Obaj księża, Zygmunt Bielawski i Walenty Gadowski, dostrzegali potrzebę zmiany katechizmu, jego treści i struktury. Poprzez publikacje zarówno o charakterze teoretycznym, jak i praktycznym - podręczniki i katechizmy, starali się przezwyciężyć model katechizmu deharbowskiego, dlatego w miejsce pytań i odpowiedzi zastosowali jednostki tematyczne. Dbali także o sposób i język przekazu prawd wiary, podkreślali potrzebę bardziej przystępnego ujmowania treści, zwłaszcza w nauczaniu dzieci. Obaj należeli do wybitnych i czołowych katechetyków polskich czterdziestolecia XX wieku.

${ }^{45}$ Por. J. Rychlicki, Ks. dr Zygmunt Bielawski, Dzieje Starego i Nowego Przymierza dla wyższych oddziałów szkól powszechnych, Lwów 1928 (recenzja), Miesięcznik Katechetyczny i Wychowawczy 18/1929, z. 7-8, s. 317.

${ }^{46}$ Por. Z. Bielawski, Dzieje biblijne..., s. 7.

${ }^{47}$ J. Rychlicki, Ks. dr Zygmunt Bielawski..., s. 317. 


\section{L'apport du prêtre W. Gadowski et du prêtre Z. Bielawski dans le triomphe sur le modèle du catéchisme de Deharbe en Pologne au début du XXè siècle}

\section{(Résumé)}

Le début du XXè siècle est une période où l'on porte un nouveau regard sur les problèmes catéchistiques et un moment de discussion sur la question du contenu de l'enseignement. En Pologne, les pionniers les plus importants concernant l'appréhension du contenu de l'enseignement en catéchisme ont été les plus grands catéchistes de cette periode-là: le prêtre W. Gadowski, partisan de l'inclusion au catéchisme de l'histoire biblique, liturgique et des textes des Prêtres de l'Église et de l'hagiographie; ainsi que le prêtre Z. Bielawski, propagateur de la limitation du contenu du catéchisme à un minimum et de l'idée de lui accorder une place à la fin du catéchisme comme résumé de toute la leçon. La manifestion de ces différentes opinions s'est faite à travers des catéchismes et des livres, qu'ils ont publié en même temps, aujourd'hui ils ne sont certainement connus que par les vieux catéchistes, mais ils méritent tout de même d'être mentionnés. Les deux catéchistes ont également apporté leur contribution constructive dans la propagation ci-nommées «La méthode de Munich » et la composition du modèle modifié du catéchisme basé sur « La théorie des degrès formels ». Le présent article montre, dans certaine partie, l'apport du prêtre W. Gadowski et du prêtre Z. Bielawski dans la triomphe du modèle du catéchisme de Deharbe qui est présent en apprentissage de la vraie foi dès la moitié du XIXè siècle. 